\title{
The Impact of Financial Information on Noise Traders: Based on the Perspective of Behavioral Finance
}

\author{
Miao Jiang* \\ University of Shanghai for Science and Technology, Yangpu District, Shanghai 200082, China. E-mail: \\ 1436847708@qq.com
}

\begin{abstract}
In China's incomplete stock market which mainly consists of retail games and short-term operations, both of the high stock turnover rate and $\mathrm{P} / \mathrm{E}$ ratios reflect excessive noise trading. This article focuses on the characteristic that individual investors are susceptible to financial media information, combined with the development and characteristics of financial media. From the perspective of behavioral finance, this paper analyzes the impact of financial media on noise trading. Using behavioral finance and psychology-related knowledge, investor behavior can be better understood, so as the motivation behind noise trading. Finally, in order to promote the healthy development of the stock market, this paper makes recommendations to improve the efficiency of the capital market.
\end{abstract}

Keywords: Noise Trading; Behavioral Finance; Financial Media; Investor Behavior

\section{Research and development of behavioral finance}

The development of behavioral finance is based on the theoretical research of classical finance,especially starting from the anomalies in the financial market. The theoretical framework of classic finance and the anomalies that appeared in the financial market are sorted out as follows.

\subsection{Classic finance and the anomalies in the financial market}

Markowitz's "Portfolio Selection" theory marked the birth of modern finance and also started many new fields in finance, which followed the Capital Asset Pricing Theory (CAPM) and efficient market theory, etc. Both theories are inseparable from the two most important premises of classical finance, the rational man hypothesis and the equilibrium hypothesis. Generally, there are three assumptions in the effective market: 1 . Investors are completely rational; 2 . There are irrational behaviors, but the impact can be offset each other; 3. Overall, irrational behaviors cannot be offset. But the market can use rational investors to balance prices. These assumptions have always occupied the mainstream of financial research and have been verified by many empirical tests. However, with the development of market, phenomena cannot gradually be explained by classic finance, especially when the investor is collectively affected by psychology, such as Shefrin and Statman (1985) investors' tendency to retain losses and Shiller's (1981) discovery of stock price volatility anomalies, etc. These practical problems raise questions about traditional assumptions, especially rational investors.

\footnotetext{
Copyright (C) 2020 Miao Jiang

doi: 10.18282/ff.v9i1.811

This is an open-access article distributed under the terms of the Creative Commons Attribution Non-Commercial License

(http://creativecommons.org/licenses/by-nc/4.0/), which permits non-commercial use, distribution, and reproduction in any medium, provided the original work is properly cited.
} 


\subsection{The emergence and development of behavioral finance}

Different from the rational assumptions in traditional finance, behavioral finance focuses on the behaviors under actual psychological influence. The first is to prove the investor behavior system will collectively deviate from the perfect Bayes rule. Representative views are the psychological account proposed by Tversky and Kahneman, which also formed the prospect theory system. In the later stage of behavioral finance, the relationship between the market and investors is deepened and behavioral finance was used as a tool to study market laws. For example, Debondt and Thaler (1985) tested the overreaction hypothesis from a 50-year market analysis. With the progress of psychology and sociology, the research methods are more abundant, combining with a lot of psychological knowledge, based on the limited arbitrage theory.

\subsection{Research on the connection between behavioral finance and noise trading}

In reality, collecting information is complicated and costs a lot and investors themselves have different capabilities to process information. Therefore, the information can't be fully complete and thus the behavior of the trader is not really rational. Based on this premise, there is the deviation which calls noise and thus noise traders are the ones who can't identify the authenticity and relevance of information. The exploration of the connection between behavioral finance and noise trading is based on the framework of noise trading theory, which breaks through the assumptions of traditional finance. Delong also proved that noise traders can survive in the market and exist in a large number of market transactions. Collecting securities information is complex and beyond capacity for individual investors in Chinese security market. Through trial and error in short-term transactions, individual investors' operation leads to the high turnover rate in the Chinese stock market. Especially, there is often a "free ride" behavior of financial media information, and thus the investors' sentiment and behavior will be affected by the media. If investors conduct noise trading and pass wrong price information to the market, they eventually weaken the market's functions such as price discovery, resource allocation and risk diversification. However, in the past research of financial news, the media is just regarded as a tool to obtain information. It is often neglected that the role in guiding investor sentiment and behavior and the impact of false news and errors which may lead to noise traders in the market. But no deep exploration has been done. The innovation of this article is to use behavioral finance to contact the media industry and the securities market, discuss the noise traders' motivation and finally suggest the ways to improve China's imperfect securities market and reduce the noise in the securities market.

\section{Current situation and problems of financial media in China's securities market}

\subsection{Current situation}

With the development and improvement of the securities market, as of February 2020, data from China Securities Depository and Clearing Corporation Limited (CSDC) shows that the number of Chinese investors has reached $1,614,484$. The huge scale and flow of the Chinese securities market require the professional and effective financial media. For a long time, most of the comprehensive financial information products have been supplied by Reuters and Bloomberg, two overseas media. However, after the "National Reserve Copper Incident", as Reuters leaked the state's material reserves to disrupt the market order, Chinese financial media realized the importance of calling the tune on financial information. Take the China's influential media platform China Business Network (CBN) as an example. CBN is the first financial media company to include daily newspapers, TV channels, radio and websites for comprehensive coverage of financial information. The figure below shows CBN's industrial chain. 


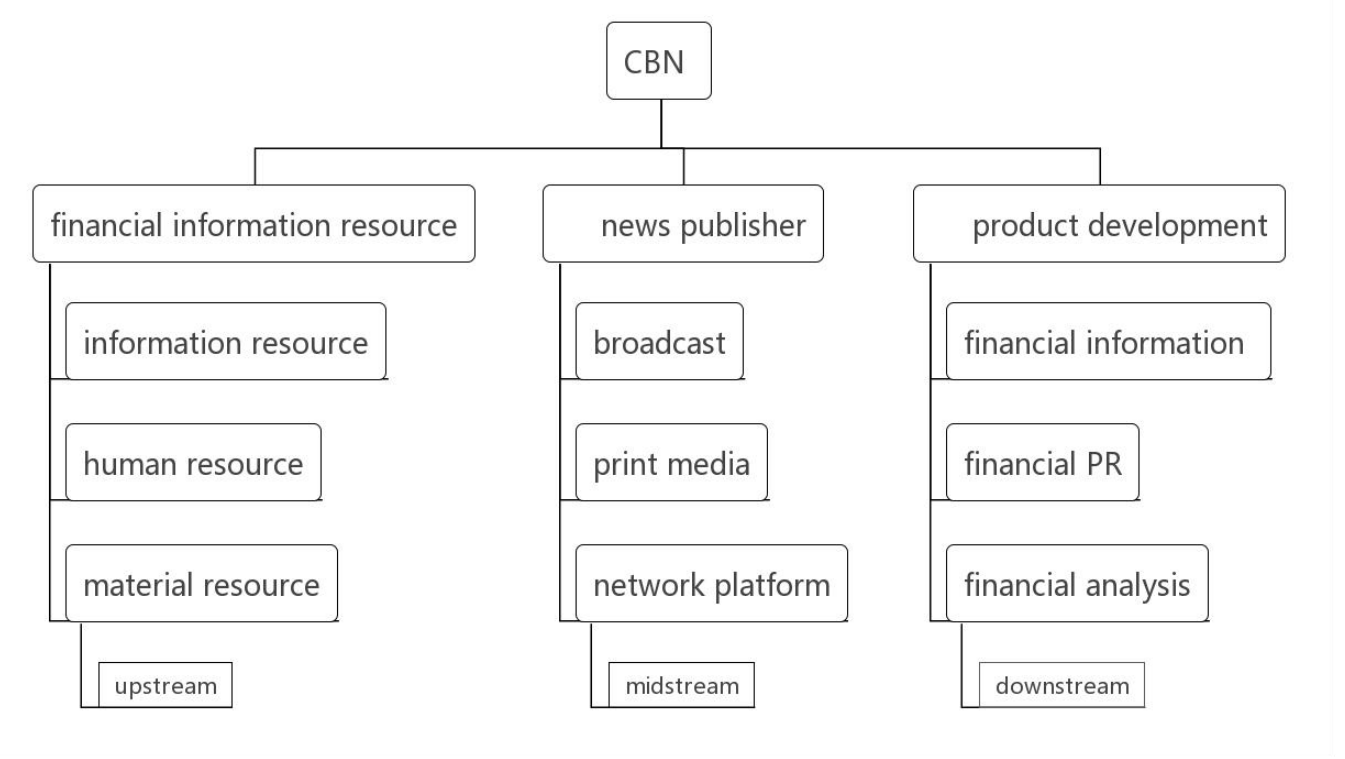

Figure 1. Industrial chain of $\mathrm{CBN}$.

CBN not only integrates a wide range of financial information resources at home and abroad, but also uses professional analysis technology and comprehensive communication channels to provide users with rich financial products and services. Meanwhile, CBN gains a wide spectrum of audience. In addition to CBN, mainstream Internet financial media such as 36 krypton has gained more than 10 million users.

\subsection{Problems}

However, the role of financial media is not limited to a simple information channel. The media industry itself has the following characteristics. Because of the sophistication of this industry, it may bring hidden dangers to the securities market.

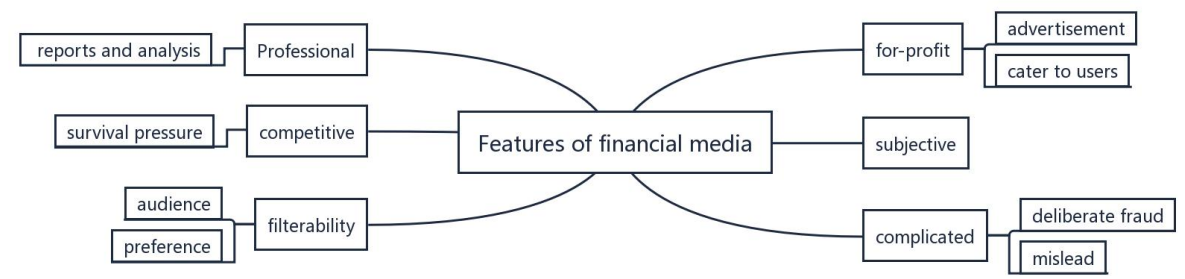

Figure 2.

Due to the heterogeneity of the media industry, financial media cannot just serve as a completely objective information tool. In addition to professional information, it needs to design attracting content to stimulate readers' attention. Faced with the survival pressure and the interests of their readers, financial reports may not only contain false information related to their advertisement interests, but also false package of the listed company for profit, which will mislead investors. Solomon believes that the media tends to publish more positive news reports to cater to investor psychology. Moreover, media communication naturally has its own filtering mechanism. Different media have different available conditions, participants, and content preferences and the audience will subjectively process the information. Finally, the market will take false feedback. As for the reason of this transmission mechanism appears in individual investors, this article uses a behavioral finance perspective to analyze the investor's behavioral characteristics, which can help understand the reasons why media information affects investors' noise trading. 


\section{Explanation of the reasons why financial media influences noise traders from the perspective of behavioral finance}

In the stock market, the daily price are rich news materials for the financial media. When it comes to money and information, investors are enthusiastic. Here, combining the characteristics of financial media and investors, this paper analyzes the motivation behind noise trading using behavioral finance theory.

\subsection{Internet financial information and investors' overconfidence}

Internet financial media often misleads noise traders who tend to overestimate their knowledge, ability and accuracy of information, which is called overconfidence. Besides, financial information on the Internet has exacerbated the illusion of controlling. Barber and Odean have found that because of the Internet's financial information, noise traders has led to speculative bubbles in the market. "National Stock Market Investor Status Report" also shows that China has the largest proportion of investors in the average holding time from January to June, indicating that China's over-trading phenomenon is serious, and Chinese investors are still blindly relying on excessive trading trial and error in the short term. Not only can the value discovery function be undermined, but also will the efficiency of the market be greatly reduced with the market full of noise.

\subsection{Rich financial information and limited attention of investors}

The abundance of information leads to scarcity of attention. Investors can only use the limited information they have to make investment judgments. In particular, the market manipulators tend to use the attention effect to disturb market order by cooperating with financial media to create false information. Individual investors who are restricted in their time and energy are more inclined to analyze the financial news that attracts their attention. With the misleading of financial media, some market participants mistakenly regard noise as useful information. This attention-driven investment transaction creates noise for the market.

In particular, it should be noted that the financial media also affects their way of thinking. Different expressions of scenarios or problems by financial media will invert people's preferences to make faulty choices. For example, faced with the same issue: when it is described as a benefit, people ignore risks; when it is described as a loss, people tend to exaggerate risks. This subjective investment deviates from the company's fundamental value. So the fluctuation of emotions violates the assumption of rational people and triggers noise in the market.

\subsection{Characteristics of financial products and investor mentality}

Financial products are more likely to be sticky with customers, allowing individual investors to rely on them and then produce a herd effect on recommended products. Especially in the current Internet era, according to CNNIC, the number of Internet news users reached 579 million, most of which are mobile phone users. Internet users are using mobile terminals to browse information for longer and longer time. The reliance on mobile terminals is more and more obvious, especially when most of the financial media have moved to online reporting. For example, Wall Street News has become the most reliant app other than WeChat with its timeline-based 24/7 real-time newsletter. Investors needs to open the app multiple times to follow the market situation. Wu Jing once used Wall Street news as an example to study the influence of financial media. The data proves that the retention rate of users of "sight" is as high as 60 to 70 percent. Investors' dependence on financial media information is not the correct basis for trading, which is often the inducement of noise trading.

In the financial market where the majority of individual investors have information costs, due to the incomplete information asymmetry in the market, humans as social animals want to follow other investors to minimize fear and to reduce the cost of collecting information as much as possible. This is where the media is the most attractive to investors. The more you lack information, the more you depend on others. The innovation of information technology has greatly increased the spread and speed of financial news. Investors who lack knowledge, experience, and other personal characteristics: knowledge, intelligence, and the ability to receive information are in need of information integration and 
analysis. Over-reliance on information will cause a group of investors to buy and sell at the same time and enter an industry sector. Decision-making depends on the herd's sense rather than company fundamentals. The herd effect described in behavioral finance relies too much on public opinion and imitates the decisions of others, instead of private information and analysis. Therefore, the guiding role of information is particularly important for individual investors. Although the purpose of buying stocks is to sell them at a high level, the common information in the market will provide a gathering channel for individual investors who are difficult to produce synergy. But following information in a noisy market is more likely to add noise.

\section{Conclusions and suggestions}

The previous analysis proves that the financial media has a significant influence on the behavior of noise traders, but the research on the influence of the financial media on the securities market needs to be further deepened, which is of great significance for cultivating investors' rational ability and improving the securities market. The following recommendations are now made from the perspective of individual investors, securities market management authorities, listed companies, and financial media:

\subsection{Cultivate rational ability}

After analysis, it is clear that rationality is not a kind of understanding, but a kind of ability. Investors should grasp the characteristic of emotions and attention and rationally treat financial media. This needs them to remind themselves not to fall into the trap, not to blindly follow the trend and to filter the information obtained, especially for retail investors. With information advantages, the banker can artificially create lagging or even false information to take advantage of the retail investors, which leads to noise in the market. Therefore, retail investors should pay more attention to improving the rational ability and skip the misleading.

\subsection{Strengthen the supervision of public opinion-oriented financial media}

When strengthening the supervision of the securities market, the supervisory authority should also pay attention to the manipulation of public opinion information leading by the financial media to prevent too much false information in the market and affect the function of the securities market. Realizing the significant influence of financial media in the securities market, attention should not only be paid to the control of the surface of quantity, word, etc., but also to the meaning of information and the motivation behind it, especially to correct and constrain the position and role of financial media in the current securities market. Therefore, in order to standardize and guide media reports, government regulators should take "fairness, openness, and impartiality" as the important rule, restrict the malicious hype of the media from the regulatory level, and cultivate media self-discipline from the institutional level. The connotation encourages objective and authentic financial media to reduce the asymmetric distribution of information in the market and balance the power gap between retail investors and institutions, thereby minimizing noise transactions caused by human factors. As a part of the overall social system, financial media should submit to the supervision of the financial market. Regulators should also improve the supervision mechanism of the entire social system and create a legal environment that is conducive to the realization of the supervision function. This is the prerequisite for the better maintenance of market order.

\subsection{Improve the information disclosure system of listed companies}

The financial media provides investors with more information about listed companies than traditional reports such as the annual reports of listed companies. So investors can understand the company's operations and situation in time. It is an important approach for investors to understand listed companies. However, in essence, the information asymmetry between listed companies and investors still exists, and the market's system for disclosing, transmitting, and disclosing information is not yet perfect. Especially at the level of listed companies, the timeliness and accuracy of the information disclosed to investors need to be further improved. Only by truly regulating the financial information 
disclosure mechanism and increasing the punishment for false information can multi-dimensional information exchange and interaction among individual investors, institutional investors, markets, and regulators be formed in a true sense.

\subsection{Cultivate the sense of responsibility of financial media}

Although financial media will inevitably have a profitable nature due to market competition, in the face of interests. But laws, regulations and responsibilities should be the first. Especially, the media should play a good role in information transmission in the securities market and shoulder their due responsibilities. Therefore, financial media must adhere to the principle of objectivity, avoid subjective opinions and reasons that affect objective information transmission, and maintain a neutral and rational attitude. The authorities can also encourage this important consciousness of the financial media through the reward and punishment system. To make the financial media accountable to investors and the market, they should observe the maintenance of the securities market order by themselves.

\section{References}

1. Shefrin H, Statman M. The disposition to sell winners too early and ride losers too long: theory and evidence. The Journal of Finance 1985. doi: 10.1111/j.1540-6261.1985.tb05002.x.

2. Shiller RJ. Do stock prices move too much to be justified by subsequent changes in dividends? Reply. The American Economic Review 1983; 73(1).

3. Kahneman D, Tversky A. Prospective Theory: An analysis of decision under risk. Routledge 2014; 8: 29-30. doi: 10.1111/1468-0262.00439.

4. Thaler R, DeBondt WF. Does the stock market over-react. The Journal of Finance 1985; 40(3): 793-805. doi: 10.1111/j.1540-6261.1985.tb05004.x.

5. Solomon DH. Selective publicity and stock prices. Journal of Finance 2012 . doi: 10.1111/j.1540-6261.2012.01726.x.

6. Barber BM, Odean T. Trading is hazardous to your wealth: the common stock investment performance of individual investors. The Journal of Finance 2000; 55(2). doi: 10.1111/0022-1082.00226.

7. Wang X, Shang W, Wang S. Analysis of the impact of Internet news media reports on China 's stock market (in Chinese). Systems Engineering Theory and Practice 2019; 39(12): 3038-3047.

8. Wu J, Liu H. Exploring the business model of new media in finance and economics based on the power of communication: Taking "Wall Street News" as an example (in Chinese). Contemporary Communication 2018; (4): 67-70. doi: CNKI:SUN:DACB.0.2018-04-027. 